\title{
Kajian Molekuler Interleukin-4 pada Aspirat Limfadenitis sebagai Faktor Risiko Kejadian Tuberkulosis Ekstra Paru
}

\author{
Humairah Medina Liza Lubis \\ Program Studi Pendidikan Dokter, Fakultas Kedokteran, Universitas Muhammadiyah Sumatera Utara \\ Jalan Gedung Arca No. 53 Medan 20217 \\ Email: humairahmedina@umsu.ac.id
}

\begin{abstract}
ABSTRAK
Pada infeksi tuberkulosis, sitokin mempunyai efek biologis metabolik seperti hipoglikemia, pireksia, inflamasi, dan dalam kadar tinggi dapat merusak sel terutama endotel, bahkan dapat menguntungkan pertumbuhan kuman karena meningkatkan sitoadherens. Pada kadar yang tepat bersifat protektif namun pada kadar yang berlebihan justru berefek patologis Timbulnya tuberkulosis ekstra paru ditentukan oleh keseimbangan antara kadar sitokin proinflamasi dan antiinflamasi, yaitu berupa rasio Interleukin $4(I L-4)$ rendah dan meningkatnya produksi IFN- $\gamma$. Tujuan dari penelitian ini adalah (1) membuktikan dan menganalisa peran Interleukin 4 sebagai faktor resiko kejadian limfadenitis tuberkulosis, (2) menjelaskan patogenesis terjadinya limfadenitis tuberkulosis berdasarkan ekspresi Interleukin 4 yang tertampil pada aspirat limfadenitis tuberculosis Penelitian ini menggunakan sampel 25 slide yang diperoleh dari pasien pembengkakan kelenjar getah bening leher dan didiagnosis sebagai limfadenitis tuberkulosis. Dilakukan pewarnaan imunositokimia dengan antigen Interleukin 4. Limfadenitis TB berupa badan-badan kecil berbentuk oval gelap di dalam kelompokan makrofag dijumpai 6 kasus positif $(67 \%)$ dan 3 kasus negatif (33\%), sedangkan limfadenitis TB berupa bercak bercak gelap dengan massa amorf eosinofilik 14 kasus positif (88\%) dan 2 kasus negatif (12\%). Dari analisa data memiliki nilai yang bermakna. Tampilan $I L-4$ pada badanbadan kecil oval berwarna gelap di dalam kelompokan beberapa makrofag dan bercak-bercak gelap dengan massa amorf eosinofilik merupakan proses imunologi terhadap bakteri basil yang masuk kedalam tubuh manusia dan dapat dipakai sebagai petanda faktor resiko kejadian limfadenitis tuberkulosis.
\end{abstract}

Kata kunci: Interleukin-4, aspirat limfadenitis, faktor resiko, tuberkulosis ekstra paru

\section{Intereukin-4 Molecular Study on Lymphadenistis Aspirate as Risk Factor of Extrapulmonal Tuberculous}

\begin{abstract}
In tuberculosis infection, cytokines have metabolic biological effects such as hypoglycemia, pyrexia, inflammation, and in high levels can damage cells, especially endothelial, can even benefit the growth of germs because it increases cytoadherens. At the right level is protective but at an excessive level it has a pathological effect. The incidence of extra pulmonary tuberculosis is determined by the balance between proinflammatory and anti-inflammatory cytokines levels, which is a low $I L-4$ ratio and increase of IFN- $\gamma$ production. The study used 25 slide samples obtained from patients with swollen neck lymph nodes and was diagnosed as tuberculous lymphadenitis. Immunocytochemical staining with Interleukin 4 antigen was performed. (1) to prove and analyze the role of Interleukin 4 as a risk factor for tuberculosis lymphadenitis, (2) to explain the pathogenesis for tuberculous lymphadenitis based on Interleukin 4 expression displayed on aspirate tuberculous lymphadenitis. TB lymphadenitis in the form of small oval-shaped bodies of macrophages grouped 6 positive cases (67\%)s and 3 negative cases $(33 \%)$ s, whereas TB lymphadenitis was in the form of dark patches with eosinophilic amorphous mass of 14 positive cases ( $88 \%$ )s and 2 negative cases $(12 \%)$ s. From the data analysis has a meaningful value. The appearance of $I L-4$ in the dark oval small bodies of groupings of multiple macrophages and dark spots with eosinophilic amorphous mass is an immunological process against bacterial bacilli that enter the human body and can be used as a marker of risk factors for tuberculosis lymphadenitis.
\end{abstract}


Keywords: Interleukin-4, lymphadenitis aspirate, risk factor, extrapulmonal tuberculous

\section{Pendahuluan}

Tuberkulosis (TB) adalah penyakit menular langsung yang disebabkan oleh kuman tuberkulosis Mycobacterium tuberculosis (MTB). Menurut World Health Organization (WHO), TB adalah penyakit yang kedua setelah Human Immuno Deficiency Virus (HIV) dan Acquired Immuno Deficiency Syndrome (AIDS) sebagai pembunuh terbesar di seluruh dunia. Prevalensi TB paru di dunia mencapai 14 juta kasus atau sama dengan 200 kasus per 100.000 penduduk. ${ }^{1}$

Di Indonesia TB merupakan masalah utama kesehatan masyarakat. Jumlah penderita TB di Indonesia merupakan ke-3 terbanyak di dunia setelah India dan Cina dengan jumlah sekitar 10\% dari total jumlah penderita TB di dunia. Diperkirakan setiap tahun ada sekitar 539.000 kasus baru dengan kematian sekitar 100.000 orang. Menurut Rattan A dkk angka kematian tiap minggu 52,000 orang atau tiap hari lebih dari 7000 orang yang meninggal. ${ }^{1}$

Tuberkulosis dapat melibatkan berbagai sistem organ di tubuh. Meskipun TB paru paling banyak dijumpai tetapi TB ekstra paru merupakan salah satu masalah klinis yang penting. Berdasarkan epidemiologi TB ekstra paru insidensinya sebanyak $15-20 \%$ dari semua kasus $\mathrm{TB}$, terutama yang melibatkan kelenjar getah bening (limfadenitis). ${ }^{2}$

Pengobatan dan kontrol terhadap penyakit TB paru dan ekstra paru telah dilakukan, tetapi akhir - akhir ini dilaporkan timbulnya resistensi kuman MTB terhadap isoniazid dan rifampisin di Amerika Serikat dan negara lainnya di dunia (resistensi multipel) termasuk di Indonesia. Terdapatnya resistensi multipel obat terhadap MTB tercermin pada meningkatnya angka kasus baru dan angka kematian serta kurang berhasilnya pengobatan terhadap penyakit TB. Pengobatan terhadap penyakit TB memerlukan waktu yang lama dan adekuat, hal ini merupakan problem kesehatan masyarakat di seluruh dunia. ${ }^{3}$ Pencegahan/pengendalian TB yang paling tepat adalah vaksinasi, namun sampai saat ini belum ditemukan vaksin yang efektif hingga $100 \%$ untuk mencegah infeksi tuberkulosis. Hasil pengkajian menunjukkan bahwa imunitas terhadap tuberkulosis sangat kompleks karena melibatkan hampir seluruh komponen sistem imun baik imunitas spesifik maupun imunitas non spesifik, imunitas humoral maupun selular yang timbul secara alami maupun didapat (acquired). Salah satu sel yang bertanggung jawab terhadap imunitas selular adalah limfosit khususnya sel limfosit $\mathrm{T}^{4}$

Pada infeksi tuberkulosis, sitokin yang terutama dihasilkan oleh makrofag merupakan respon imun non-spesifik (innate immunity) yang ditujukan untuk menghambat pertumbuhan kuman secara tidak langsung dengan mengaktifkan leukosit untuk menghasilkan radikal bebas yang akan mematikan parasit. Selain itu, sitokin berfungsi mengaktifkan sel-sel imun lain seperti makrofag, limfosit $\mathrm{T}$, limfosit $\mathrm{B}$ dan sel NK untuk berproliferasi dan menghasilkan lebih banyak mediator guna bekerja sama 
mengatasi infeksi. Di lain pihak, sitokin mempunyai efek biologis metabolik seperti hipoglikemia, pireksia, inflamasi, dan dalam kadar tinggi dapat merusak sel terutama endotel, bahkan dapat menguntungkan pertumbuhan kuman karena meningkatkan sitoadherens (melalui peningkatan ekspresi molekul adhesi pada endotel). Di sini terlihat bahwa sitokin memiliki peran ganda seperti "pedang bermata dua", pada kadar yang tepat bersifat protektif namun pada kadar yang berlebihan justru berefek patologis. ${ }^{4}$

Berdasarkan jenis sitokin yang dihasilkannya, limfosit $\mathrm{T}$ helper dibagi menjadi Th1 yang menghasilkan sitokin proinflamasi IFN- $\gamma$, TNF- $\alpha$, TNF- $\beta$ (juga disebut sebagai limfotoksin, LT), IL-1, IL-6, IL-8, IL-12; berfungsi mengaktifkan imunitas seluler dan imunitas non-spesifik. Sedangkan Th2 yang menghasilkan sitokin anti inflamasi IL-4, IL-10; berfungsi mengaktifkan imunitas humoral. ${ }^{5}$ Timbulnya tuberkulosis ekstra paru ditentukan oleh keseimbangan antara kadar sitokin proinflamasi dan anti-inflamasi, yaitu berupa rasio $I L-4$ rendah. Rendahnya produksi $I L-4$ berhubungan dengan meningkatnya produksi IFN- $\gamma$. Dari penelitian Anshari A mengemukakan bahwa, terdapat hubungan kerentanan dan tingkat keparahan TB dengan pemeriksaan sitokin diantaranya $I L-10$ yang dapat menurunkan kerusakan jaringan kolateral dan $I F N \gamma$ yang berperan sebagai protektif dalam penyakit pada paru tertentu. ${ }^{6}$ Timbul asumsi bahwa gambaran mikroskopis dari limfadenitis tuberkulosis berupa kerusakan jaringan berhubungan dengan penurunan produksi ILA. Berdasarkan asumsi tersebut, peneliti tertarik untuk melakukan penelitian terhadap sitokin $I L-4$ tersebut yang diduga akan meningkatkan risiko timbulnya limfadenitis TB. Dari literatur yang didapatkan sampai saat ini belum ada data di Indonesia mengenai peran IL-4 dan pengaruhnya terhadap kejadian limfadenitis TB.

Penelitian sitokin $I L-4$ ini akan menjelaskan patogenesis terjadinya limfadenitis TB dari segi imunologi. Dengan temuan ini nantinya akan dilanjutkan dengan pembuatan vaksin dan terapi oral berbasis sitokin agar tidak timbul resistensi terhadap obat TB seperti yang sering ditemukan saat ini. Pengobatan yang tepat akan menyelamatkan banyak jiwa dan diharapakan Indonesia akan terbebas dari penyakit tuberkulosis.

Berdasarkan latar belakang di atas dapat disimpulkan permasalahan dalam penelitian ini yaitu mengenai peran $I L-4$ merupakan molekul sebagai faktor resiko terjadinya limfadenitis tuberculosis. Penelitian ini bertujuan untuk (1) membuktikan dan menganalisa peran $I L-4$ sebagai faktor resiko kejadian limfadenitis tuberkulosis, (2) menjelaskan patogenesis terjadinya limfadenitis tuberkulosis berdasarkan ekspresi $I L-4$ yang tertampil pada aspirat limfadenitis tuberkulosis. Penelitian ini bermanfaat untuk (1) menemukan terapi baru untuk pengobatan TB, (2) merencanakan terapi imun anti TB baru kearah pro inflamasi atau anti inflamasi antara lain dengan memberikan vaksin dengan komponen $I L-4$ (3).

Penelitian ini bertujuan untuk membuktikan dan menganalisa peran $I L-4$ 
sebagai faktor resiko kejadian limfadenitis tuberkulosis, menjelaskan patogenesis terjadinya limfadenitis tuberkulosis berdasarkan ekspresi IL-4 yang tertampil pada aspirat limfadenitis tuberkulosis.

Penelitian ini bermanfaat untuk (1) menemukan terapi baru untuk pengobatan TB, (2) merencanakan terapi imun anti TB baru kearah pro inflammatory atau anti iflammatory antara lain dengan memberikan vaksin dengan komponen Interleukin-4, (3) sumbangsih ilmu pengetahuan dengan penemuan vaksin baru pencegah dan pengobatan TB dan berkontribusi untuk mencegah terjadinya Multi Drug Resistance terhadap obat TB konvensional yang didapatkan selama ini.

\section{Metode Penelitian}

Penelitian ini merupakan penelitian analitik dengan menggunakan rancangan potong lintang (cross-sectional study). Penelitian dimulai dengan diagnosis sediaan sitologi limfadenitis tuberkulosis berupa badan-badan kecil berbentuk oval gelap didalam kelompokan makrofag dan bercakbercak gelap dengan massa amorf eosinofilik ${ }^{7}$ di laboratorium Patologi Anatomi Fakultas Kedokteran Universitas Muhammadiyah Sumatera Utara. Kemudian dilakukan pulasan imunositokimia $I L-4$. Selanjutnya dilakukan interpretasi dan penghitungan ekspresi protein IL-4 pada ke-25 sampel penelitian.

Preparat yang memperlihatkan warna coklat berarti mengandung protein $I L-4$, sedangkan preparat yang menunjukkan warna biru seperti kontrol negatif berarti tidak mengandung protein $I L-4$. Setiap kali pewarnaan harus disediakan kontrol negatif dan kontrol positif. Proses-proses yang dilakukan untuk membuat preparat imunositokimia $I L-4$ maupun pengecatan imunositokimia $I L-4$ dilakukan sesuai prosedur standar pengecatan yang dilakukan di laboratorium terpadu Fakultas Kedokteran Universitas Muhammadiyah Sumatera Utara.

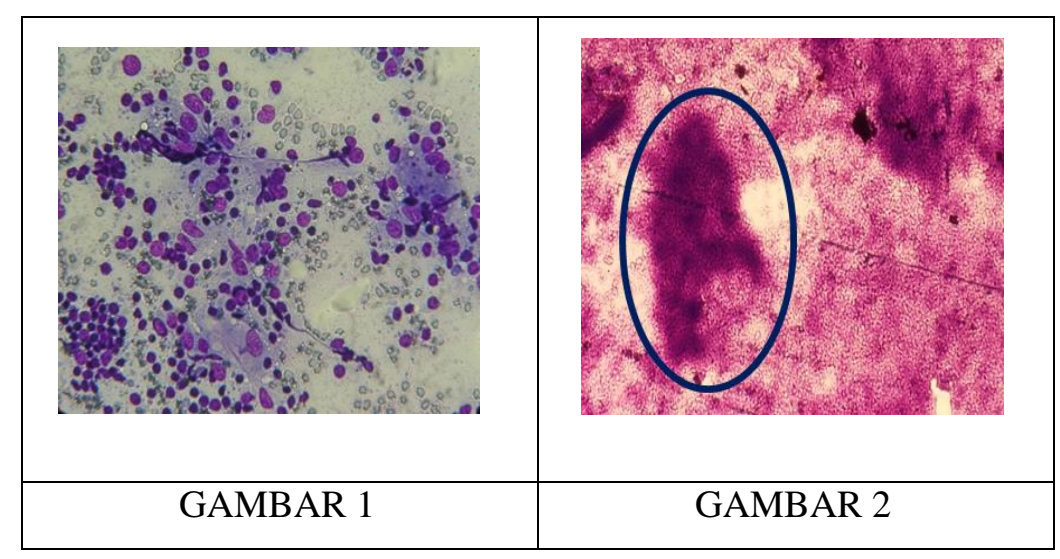




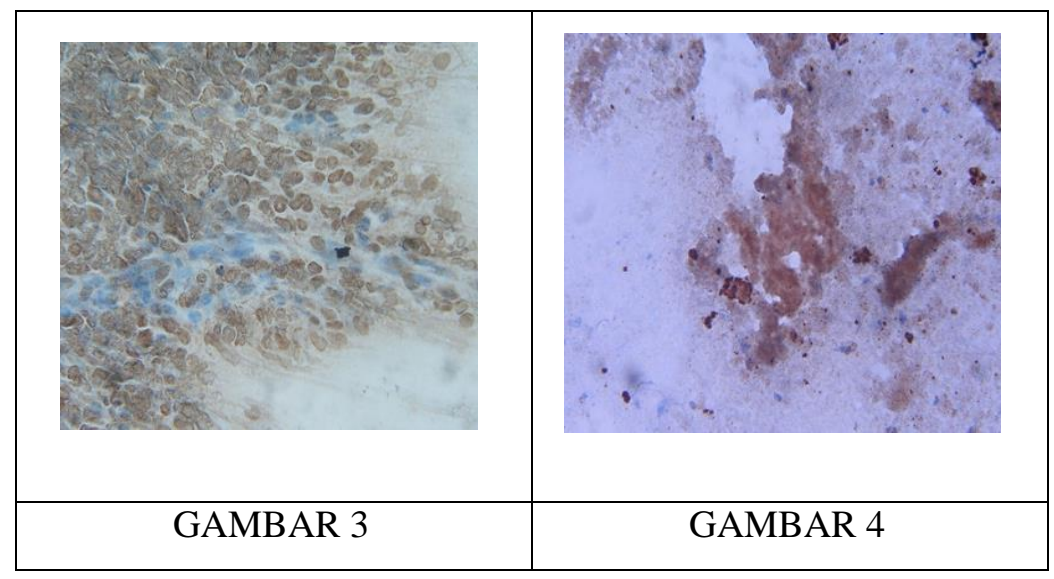

Keterangan:

a. Gambar 1. Badan-badan kecil berbentuk oval berwarna gelap di dalam kelompokan beberapa makrofag (MGG, 400x)

b. Gambar 2. Aspirat dengan bercakbercak gelap dengan massa amorf bergranula halus eosinophil

c. Gambar 3. IL-4 positif kuat pada limfadenitis TB berupa badan-badan kecil berbentuk oval gelap didalam kelompokan makrofag

d. Gambar 4. IL-4 positif kuat pada limfadenitis TB berupa bercak-bercak gelap dengan massa amorf eosinofilik

\section{Hasil}

Tabel 1. Persentase diagnosis sitologi

\begin{tabular}{llll}
\hline & Diagnosis Sitologi & n & \% \\
\hline Limfadenitis & - Badan-badan & 9 & 36 \\
& kecil berbentuk & & \\
oval gelap di & & \\
& dalam & & \\
& kelompokan & & \\
& makrofag & & \\
- & Bercak-bercak \\
& gelap dengan \\
& massa amorf & 16 & 64 \\
& & & \\
eosinofilik & & \\
Jumlah & $\mathbf{2 5}$ & $\mathbf{1 0 0}$ \\
\hline
\end{tabular}

Pada pemeriksaan biopsi aspirasi jarum halus dengan pewarnaan $M G G$ diperoleh diagnosis: limfadenitis TB berupa badan-badan kecil berbentuk oval gelap di dalam kelompokan makrofag 9 kasus (36\%), dan limfadenitis TB berupa bercak bercak gelap dengan massa amorf eosinofilik 16 kasus (64\%).

Dilakukan pewarnaan imunositokimia $I L-4$ untuk dapat menilai tampilan masing-masing sampel. Penilaian diagnosis: limfadenitis TB berupa badanbadan kecil berbentuk oval gelap di dalam kelompokan makrofag dijumpai 6 kasus positif (67\%) dan 3 kasus negatif (33\%), sedangkan limfadenitis TB berupa bercak bercak gelap dengan massa amorf eosinofilik 14 kasus positif (88\%) dan 2 kasus negatif (12\%). (Lihat tabel 2). Dari analisa data memiliki nilai yang bermakna.

Dari 6 kasus tampilan ekspresi $I L-4$ pada limfadenitis TB berupa badan-badan kecil berbentuk oval gelap di dalam kelompokan makrofag didapatkan 5 kasus ekspresi kuat dan 1 ekspresi sedang. Sedangkan 14 kasus tampilan ekspresi $I L-4$ 
pada limfadenitis TB berupa bercak bercak gelap dengan massa amorf eosinofilik didapatkan 12 kasus ekspresi kuat dan 2

ekspresi sedang.

Tabel 2. Tampilan Imunositokimia $I L-4$ pada Sitologi Limfadenitis

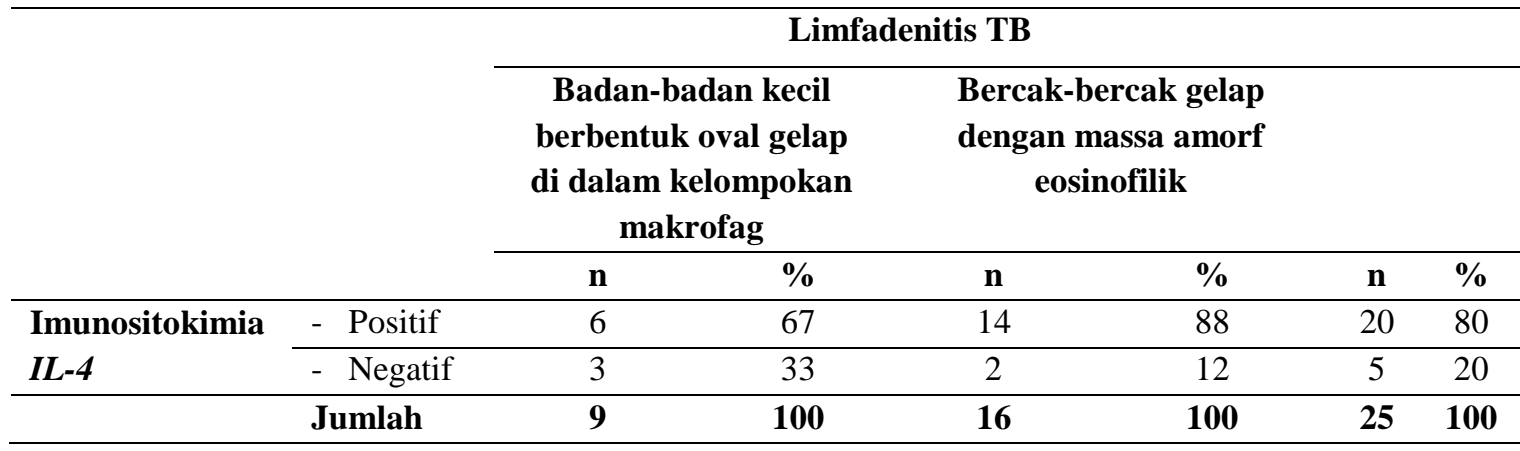

\section{Pembahasan}

Dari pengamatan kami terhadap beberapa kasus dengan tidak ditemukannya struktur konvensional tuberkulosis dengan gambaran sel Langhans giant cell dan sel epitoloid tetapi tampak adanya badan-badan kecil berbentuk oval gelap di dalam kelompokan makrofag dan bercak-bercak gelap dengan massa amorf eosinofilik pada latar belakangnya, kami mendiagnosis gambaran tersebut berupa limfadenitis tuberkulosis yang didukung dengan penelitian dari Lubis HML dkk tahun 2008, kami melanjutkan penelitian ini dengan menggunakan $I L-4$ sebagai sitokin anti inflamasi.

Dari hasil yang didapatkan dengan tertampilnya sitokin $I L-4 \quad$ tersebut menunjukkan bahwa sitokin yang terutama dihasilkan oleh makrofag merupakan respon imun non-spesifik (innate immunity) yang ditujukan untuk menghambat pertumbuhan kuman secara tidak langsung dengan mengaktifkan leukosit untuk menghasilkan radikal bebas yang akan mematikan parasit. Selain itu, sitokin berfungsi mengaktifkan sel- sel imun lain seperti makrofag, limfosit $\mathrm{T}$, limfosit B dan sel NK untuk berproliferasi dan menghasilkan lebih banyak mediator guna bekerja sama mengatasi infeksi. Di lain pihak, sitokin mempunyai efek biologis metabolik seperti hipoglikemia, pireksia, inflamasi, dan dalam kadar tinggi dapat merusak sel terutama endotel, bahkan dapat menguntungkan pertumbuhan kuman karena meningkatkan sitoadherens (melalui peningkatan ekspresi molekul adhesi pada endotel). Di sini terlihat bahwa sitokin memiliki peran ganda seperti "pedang bermata dua", pada kadar yang tepat bersifat protektif namun pada kadar yang berlebihan justru berefek patologis. ${ }^{4}$

Dari penelitian ini perlu dilakukan penelitian selanjutnya dengan menggunakan sitokin pro inflamatori seperti IFN- $\gamma$, TNF- $\alpha$, TNF- $\beta$ (juga disebut sebagai limfotoksin, LT), IL-1, IL-6, IL-8, IL-12 sebagai penyeimbang karena kerja dari pro inflamatori dan anti inflamatori harus bersama-sama dan tidak bisa berdiri sendiri.

Juga dapat dilakukan penelitian lanjutan dengan antibodi pro inflamatori yang lain agar 
patogenesis linfadenitis tuberkulosis dengan gambaran non konvensional diatas dapat dijelaskan dengan akurat.

\section{Kesimpulan dan Saran}

Berdasarkan studi pendahuluan ini kami dapat menyimpulkan bahwa $I L-4$ dapat dipakai sebagai petanda (faktor resiko) kejadian tuberkulosis. Penelitian ini dapat dilanjutkan ke tingkat yang lebih tinggi dengan sampel yang lebih banyak untuk mendapatkan vaksin baru pencegah TB dan sebagai target terapi TB dengan menggunakan anti inflamasi dan pro inflamasi. Mencari sponsor vaksin dan obat agar penelitian ini dapat berkembang dan berguna bagi masyarakat.

\section{Daftar Pustaka}

1. Kumar V, Abbas AK, Fausto N, Aster JC. 2010. Robbins and Cotran. Basic Pathology Basis of Disease $8^{\text {th }}$. Ed. Philadelphia: Saunders.

2. Perkins DJ, Were T, Davenport GC, Kempaiah P, Hittner JB, Ong'echa JM. 2011. Severe malarial anemia: innate immunity and pathogenesis. Int $\mathbf{J}$ Biol Sci.;7(9):1427-42.

3. American Society of Microbiologi. pp. 131-134.

4. Nugroho A. Patogenesis malaria berat. In: Harijanto PN, Nugroho A, Gunawan CA, editors.Malaria-dari molekuler ke klinis. 2nd ed. Jakarta: EGC, 38-63; 2008.

5. Clark I. A, Budd A. C, Alleva LM, Cowden WB. 2006. Human malarial disease:a consequences of inflammatory cytokine release. Malaria journal; 5:85:32.

6. Ansari A, Talat N, Jamil B, Hasan Z, Razzaki T, et al. 2009. Cytokine Gene Polymorphisms across Tuberculosis Clinical Spectrum in Pakistani Patients. PLoS ONE 4(3): 4778.

7. Lubis HML, Lubis HML, Lisdine, Hastuti NW. 2008. Dark specks and eosinophilic granular necrotic material as differentiating factors between tuberculous and nontuberculous abscess. Majalah Patologi; 2:49-52. 